\title{
SOLAR THERMAL CONTROL OF BUILDING INTEGRATED PHASE CHANGE MATERIALS: AN EXPERIMENTAL SURVEY
}

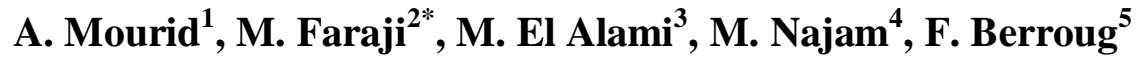 \\ ${ }^{1,2,3,4}$ Hassan II University, Faculty of Sciences Ain Chock, Physics Department, LPMMAT Laboratory, Casablanca- \\ Morocco \\ ${ }^{5}$ Cadi Ayyad University, Faculty of Sciences Semlalia, Physics Department, LAEPT Laboratory, Marrakech- Morocco \\ ${ }^{(*)}$ Corresponding author Email: farajimustapha@yahoo.fr, phone: +212 0631756990
}

\begin{abstract}
In the present paper, we study experimentally the thermal behavior of phase change material (PCM) for thermal control of indoor applications. The experimental setup consists of two full scale identical concrete cavities, situated in Faculty of Sciences Aïn Chock in Casablanca- Morocco $\left(33^{\circ} 36^{\prime} \mathrm{N}, 07^{\circ} 36^{\prime} \mathrm{W}\right)$. The first cavity incorporates paraffinic phase change material with melting temperature of $22{ }^{\circ} \mathrm{C}$ and second cavity is built with alveolar bricks. The test cells are equipped by set of thermocouples and heat flux meters connected to data logger. Thermal analysis for the two cubicles was conducted. The results show that inner temperature swings decreases remarkably in the cavity with $P C M$ with temperature minima $3^{\circ} \mathrm{C}$ upper to the case without $P C M$. On the other hand, there is time shift between PCM cavity and the reference cavity temperature oscillations. The integration of the phase change material on the roof of the building reduces the temperature of internal walls as it has good thermal inertia. When PCM panel covered the roof, solar heat transmission is reduced. This significantly reduces the ambient temperature of the cell. This demonstrates the ability of PCM to increase the thermal comfort of buildings.
\end{abstract}

Keywords: PCM, Thermal Comfort, Building, Passive Solar Heating, Heat Storage. Melting, Solidification

\section{INTRODUCTION}

Energy consumption for the air conditioning inside the housing is becoming increasingly important for the modern buildings. This type of construction generally uses lightweight materials, low heat storage capacity, which usually requires the use of artificial air conditioning. To improve the thermal performance of the habitat in a passive way, different types of phase change materials are used: inorganic, organic and eutectic. These PCMs are incorporated into different components of construction: walls, slabs and floors. Phase change materials (PCM) can be used in building using solar energy for heating or night cold for cooling. During the process of melting and solidification of the PCM incorporated in building structure, a large amount of energy can be absorbed or released over a very small temperature range, enabling PCM to act as a heat reservoir nearly isothermal. Selecting PCM essentially concerns its melting temperature, its latent heat capacity and cost. Different types of PCMs and their characteristics are described in literatures. Paraffin-based PCMs are commonly used in buildings because of their appropriate melting temperature, their large capacity for latent heat, stable chemical properties, nontoxicity and low cost. One concern of using paraffin in building constructions is its flammability. The wallboards are cheap and widely used in a variety of applications, making them very suitable for PCM encapsulation. However, the principles of latent heat storage can be applied to any appropriate building materials. The idea of improving the thermal comfort of lightweight buildings by integrating
PCMs into the building structure has been investigated in various research projects since before 1975 by Barkmann et al. ${ }^{1}$, Kedl et al. ${ }^{2}$ and Salyer et al. ${ }^{3}$, Shapiro et al. ${ }^{4,5}$ and by Feldman et al. ${ }^{6}$. Most of these attempts applied PCM macrocapsules or direct PCM immersion processes. PCMs have been incorporated into gypsum wallboards to provide passive energy storage. For integration into the walls, the PCM layer may be sandwiched between the inner and outer walls, absorbed in porous concrete, or impregnated plasterboard ${ }^{7,8}$. Faraji et al. ${ }^{9}$ performed a numerical study of the thermal performance of a concrete/paraffin/hydrate salt composite wall used for heating management of building. The solar energy absorbed by the wall is stored in a phase change material (PCM). It was found that, when the PCM layer is set closer to the inner face of the wall, thermal comfort conditions are considerably improved compared to a concrete wall without PCM. Castell et al. ${ }^{10}$ obtained energy consumption reductions of $15 \%$ when PCM was implemented in building envelopes. The objective of the present work is to evaluate the thermal performance of envelope of residential buildings equipped with a phase change material. An ordinary test cavity has been used as a reference. The field trials were carried out with two identical cells. The PCM was installed on the roof and/or in vertical walls. The thermal performance of the walls was compared with those of the reference cell by measuring their conductive heat flux, internal walls temperatures and cells ambient temperatures. 


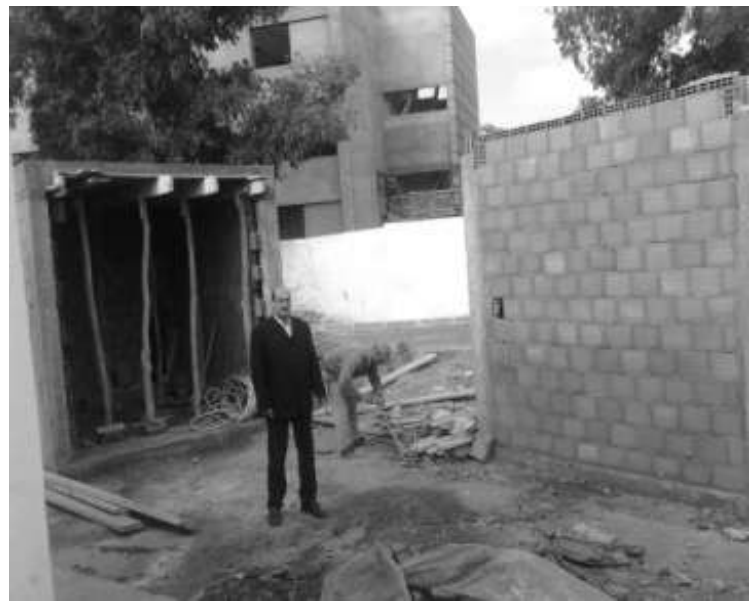

Fig 1. (a)

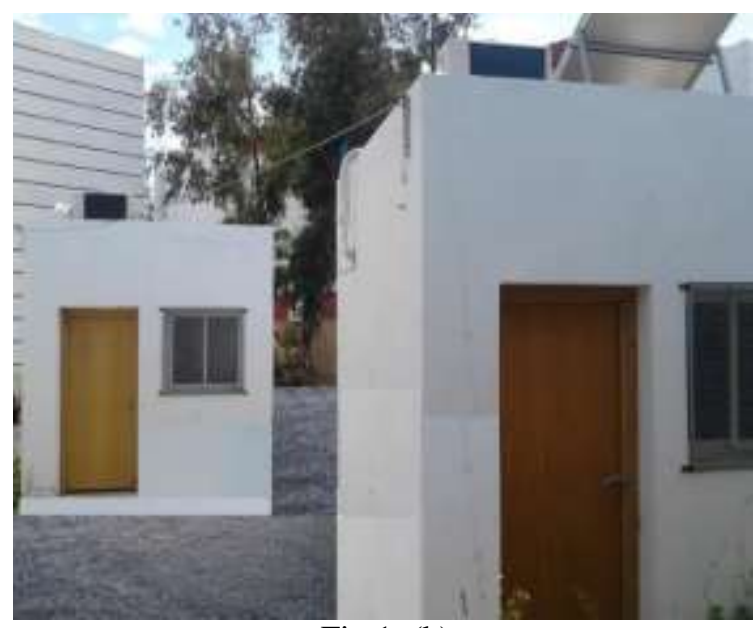

Fig 1. (b)

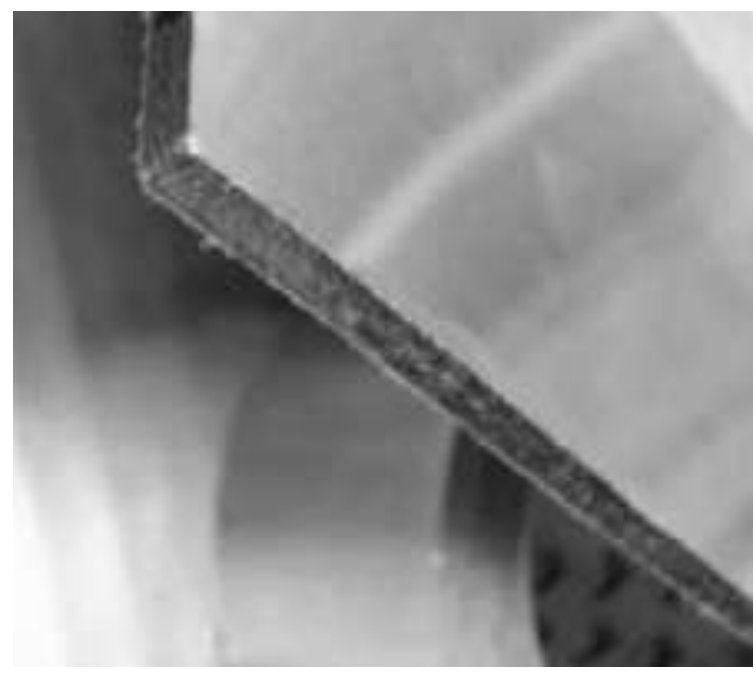

Fig 1. (c)

Figure 1: Experimental setup full scale size: cubicles construction stages (a) under building, (b) finish. (c) PCM panels.

\section{EXPERIMENTAL FACILITY}

\subsection{Experimental setup}

Figure 1-a,b shows the experimental setup located in Casablanca, Morocco $\left(33^{\circ} 36^{\prime} \mathrm{N}, 07^{\circ} 36^{\prime} \mathrm{W}\right)$. It consists of two full scale cubicles with the same internal dimensions $(2.8 \times 2.8 \times 2.8 \mathrm{~m})$, equipped with glazed window $(1 \times 1 \mathrm{~m})$ and a door $(2 \times 1 \mathrm{~m})$, in the north wall. The constructive systems of these rooms are:

- Reference cubicle: built with alveolar bricks system based on two layers of bricks as follows: $2 \mathrm{~cm}$ mortar, 7 $\mathrm{cm}$ red bricks, $14 \mathrm{~cm}$ air gape, $7 \mathrm{~cm}$ red bricks and $1 \mathrm{~cm}$ mortar, successively. The roof was built by full paving stone concrete.

- PCM cubicle: built as the previous cubicle adding a PCM panels in the inner faces of the vertical walls and on the roof. PCM consist of Energain paraffin panels, Figure 1-c.

\subsection{Phase Change Material (PCM)}

The phase change material used is Rubitherm-Energain, product manufactured by Dupont de Nemours Company (Luxembourg). This PCM is a rectangular panel with dimensions of $1 \times 1.2 \mathrm{~m}$ and embedded in a thin aluminum cover. The shape of the PCM material is flexible aluminum sheet of $5.26 \mathrm{~mm}$, Figure 1 (c). The panel contains $40 \%$ of solid compound (copolymer ethylene) and $60 \%$ of paraffin. It is characterized by a melting temperature of $21.7^{\circ} \mathrm{C}$ and an enthalpy of $70 \mathrm{~kJ} / \mathrm{kg}$. The thermal conductivity is $0.18 \mathrm{Wm}^{-}$ ${ }^{1} \cdot \mathrm{K}^{-1}$ in solid phase and $0.14 \mathrm{Wm}^{-1} \cdot \mathrm{K}^{-1}$ in liquid phase. Rubitherm-Energain $\mathrm{PCM}$ was selected to be used in the cubicle because it store and release large quantities of thermal energy at nearly constant temperature, The use of one Energain panel of $5 \mathrm{~mm}$ thickness is equivalent to $30 \mathrm{~mm}$ of concrete. It is chemically inert, long life product and stable performances during phase change cycles also, the melting temperature is close to human comfort. Table 2 summarizes the main thermal properties of the PCM.

Table 1 summarizes the geometrical dimensions of the cubicle walls.

Table 1: Envelop materials (from interior to exterior) (a), Vertical walls thermal properties (b), Roof structure and materials properties (c)

\begin{tabular}{ccc}
\hline Wall & Material & Thickness(mm) \\
\hline \multirow{2}{*}{ Roof } & Mortar & 20 \\
\cline { 2 - 3 } & Concrete & 120 \\
\cline { 2 - 3 } Vertical wall & Mortar & 20 \\
\cline { 2 - 3 } & PCM & 5.26 \\
\cline { 2 - 3 } & Air layer & 14 \\
\cline { 2 - 3 } & Mortar & 10 \\
\cline { 2 - 3 } & Brick & 70 \\
\cline { 2 - 3 } & Air layer & 140 \\
\cline { 2 - 3 } Floor & Brick & 70 \\
\cline { 2 - 3 } & Mortar & 10 \\
\cline { 2 - 3 } & Mortar & 100 \\
\hline Glazed & Plaster & 50 \\
façade & Concrete & 100 \\
\hline
\end{tabular}

(a) 


\begin{tabular}{cccccc}
\hline & Mortar & Alveolar & Air & Alveolar & Mortar \\
\hline $\mathrm{e}(\mathrm{cm})$ & 1 & 7 & 14 & 7 & 1 \\
\hline $\mathrm{c}_{\mathrm{p}}(\mathrm{kJ} / \mathrm{kg} . \mathrm{k})$ & 0.84 & 0.79 & 1.23 & 0.79 & 0.84 \\
\hline$\lambda(\mathrm{W} / \mathrm{m} . \mathrm{k})$ & 1.15 & 0.47 & 0.09 & 0.47 & 1.15 \\
\hline
\end{tabular}

(b)

\begin{tabular}{lll}
\hline & Mortar & $\begin{array}{l}\text { Full paving } \\
\text { concrete(roof) }\end{array}$ \\
\hline $\mathrm{e}(\mathrm{cm})$ & 20 & 15 \\
\hline $\mathrm{c}_{\mathrm{p}}(\mathrm{kJ} / \mathrm{kg} . \mathrm{k})$ & 0.84 & 0.92 \\
\hline$\lambda(\mathrm{W} / \mathrm{m} . \mathrm{k})$ & 1.15 & 1.75 \\
\hline
\end{tabular}

(c)

\subsection{Instrumentation and Measurements}

The cells are instrumented with 75 thermocouples K-type $(2 / 10 \mathrm{~mm})$ with an accuracy of $\pm 2 \%$. They are carefully welded, ensuring that the weld is of the same diameter that the two wires. Then, they are calibrated and the assembly is connected to a data acquisition device, Figure 2-a. Note that the thermocouples are distributed in order to access to the average temperatures of all the walls and the indoor temperature of the cells.

We have also conducted heat flux density measurements through the walls of the room with heat flux captors, Figure 2 -b, having an accuracy of $\pm 3 \%$ and a 0.3 s response time. The considered case is a room with one person and personal computer, corresponding to $300 \mathrm{~W}$ internal gains ${ }^{11}$.

Are registered with 10 minutes frequency:

- Internal walls temperatures and also external temperature.

- Internal ambient temperature (at a height of $1.5 \mathrm{~m}$ ).

- Heat fluxes at the cubicles faces.

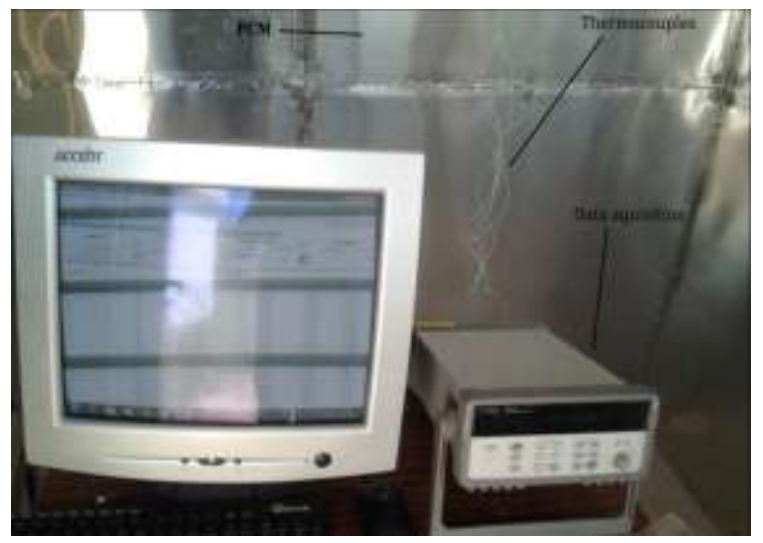

(a)

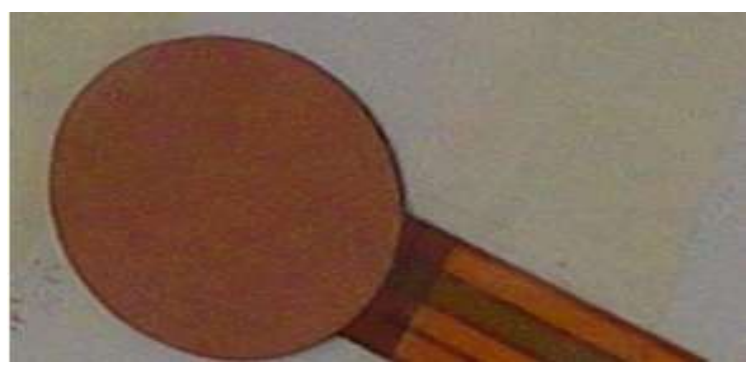

(b)

Figure 2: Thermocouples and Data Acquisition System (a). Heat flux sensor (b)

\subsection{Meteorological Data}

The experiments were carried out for free external radiations and temperature conditions during March and August 2014. Meteorological station, fixed on the roof of the test cells, was used to register the outdoor ambient temperature, solar radiation, wind velocity and wind direction and relative humidity. All data are stored in a desk computer using data logger.

\section{RESULTS AND DISCUSSION}

The results from the experimental test in the cubicles with and without PCM were obtained from 2014 during the periods of Mars, 09 to 13: heating period, and August, 26 to 31: air refreshing period.

\subsection{Heating Period: PCM in Vertical Walls}

Figure 3 analysis shows that minimum outdoor temperatures are obtained during the night. On average, temperatures minima and maxima range between $10^{\circ} \mathrm{C}$ and $23{ }^{\circ} \mathrm{C}$, respectively, and the ambient temperature swings between these extremes. During the first 7 hours every day, solar radiations rises and the ambient outdoor temperature increases. Solar radiation reaches a maximum value, 720 $\mathrm{W} / \mathrm{m}^{2}$ and falls to zero at the sunset. Casablanca city climate is characterized by significant temperature fluctuations with lower nocturnal values of temperature. None controlled building will demand more energy for heating purpose.

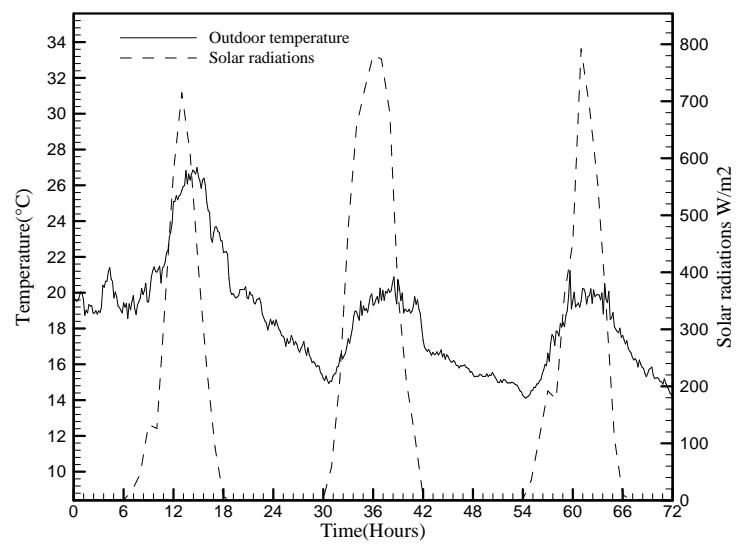

Figure 3: Time wise variations of the external ambient temperature and solar radiations, (Casablanca, Morocco $\left.33^{\circ} 36^{\prime} \mathrm{N}, 07^{\circ} 36^{\prime} \mathrm{W}\right)$

Table 2: Thermal properties of the Energain $\mathrm{PCM}^{12}$

\begin{tabular}{|l|l|}
\hline Parameter & Value \\
\hline Melting point & $21.7 \mathrm{C}$ \\
\hline $\begin{array}{l}\text { Combined Heat storage capacity (latent and } \\
\text { sensible heat in a temperature range of } 14 \text { to } \\
29^{\circ} \mathrm{C} \text { ) }\end{array}$ & $>170$ \\
\hline Specific heat capacity & \\
\hline Conductivity - solid phase & $>70$ \\
Conductivity - liquid phase & $\mathrm{kJ} / \mathrm{kg} \mathrm{K}$ \\
& 0.18 \\
& $\mathrm{~W} / \mathrm{m} \mathrm{K}$ \\
& 0.14 \\
& $\mathrm{~W} / \mathrm{m} \mathrm{K}$ \\
\hline
\end{tabular}




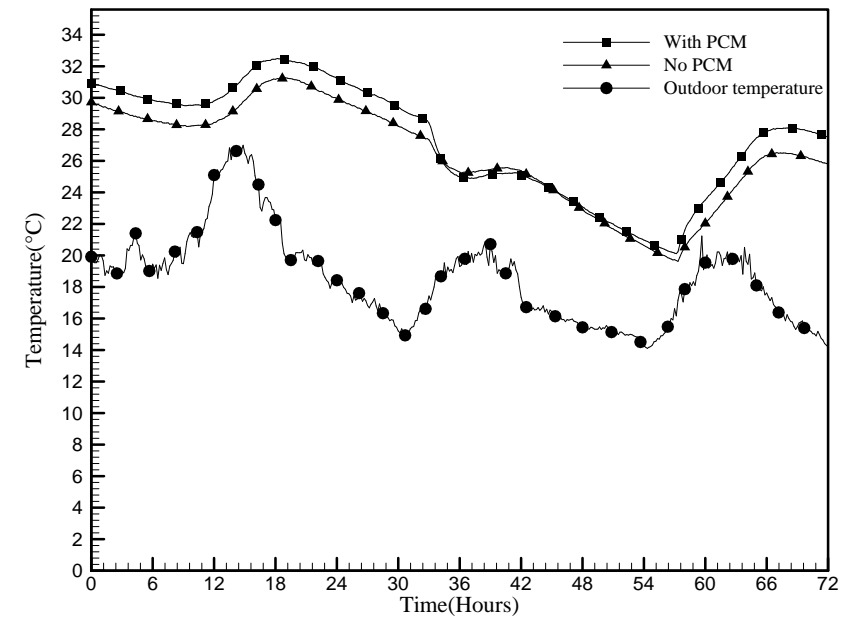

Figure 4: Time wise variations of the external ambient temperature and south walls temperature for cubicles with and without PCM, (Casablanca, Morocco 33 $\left.36^{\prime} \mathrm{N}, 07^{\circ} 36^{\prime} \mathrm{W}\right)$

Figure 4 shows the time variations of the temperature of south wall of both cubicles. Data analysis shows that the thermal reduction is slower in the PCM cubicle case, since it has stored more heat (latent) during a day. Remember that ambient temperature vary between $10{ }^{\circ} \mathrm{C}$ to $23{ }^{\circ} \mathrm{C}$, but the building walls receive also solar irradiative heat flux absorbed by the concrete having solar absorption coefficient of 0.8 , combined with internal loads and convective heat flux. A thermal gain leads to the increase of the PCM temperature to its melting point. During the night, when the PCM undergoes phase change, the slop of PCM wall temperature curve weakens because the solidification of PCM occurs at a nearly constant temperature. Sensible heat dissipation is disabled and the decrease of the PCM cubicle nocturnal temperature is shifted. Composite PCM-Concrete walls can be considered as an important heat storage device. The stored heat during a day is naturally released for heating needs in the following cold night with less temperature fluctuations.

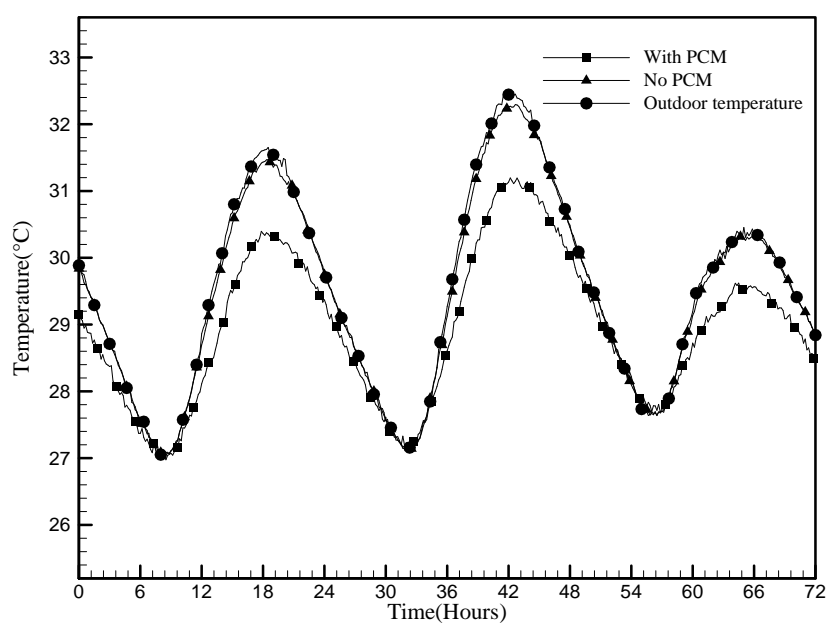

Figure 5: Outdoor and indoor ambient temperatures for cubicles with and without PCM on the roof

\subsection{Refreshing Period: PCM on the Roof}

In order to minimize heat gain in the summer, PCM panels were placed on the roof of the test cell. The flow to be transmitted by conduction to the inside will be converted by the PCM as latent heat of fusion. To demonstrate this process, we will compare the internal ambient temperature of the PCM room to those of the reference room. The results were obtained from 26 to 31 August 2014. Figure 5 sketches the experimental result according to the indoor ambient temperatures for cubicles with and without PCM on the roof. It was emerged that, the inner ambient temperature of the cell without PCM is practically identical with the outside temperature because of low thermal inertia of local. For the case of cubicle with PCM roof, the room has good thermal inertia and PCM contributes to refresh the air and an inner temperature is decreased about $2{ }^{\circ} \mathrm{C}$, because that, during the melting of the PCM, sensible heat gain is disabled and the increase of the PCM cubicle diurnal temperature is shifted. During the night, the cancelation of solar radiations and the fall of the external temperature promote the freezing of PCM. Also, sensible heat accumulated during the hot day is released to the exterior and to the PCM at nocturnal phase. An important amount of cold is stored in the crystallized PCM at night and will be used passively to refreshing the room during the following day.

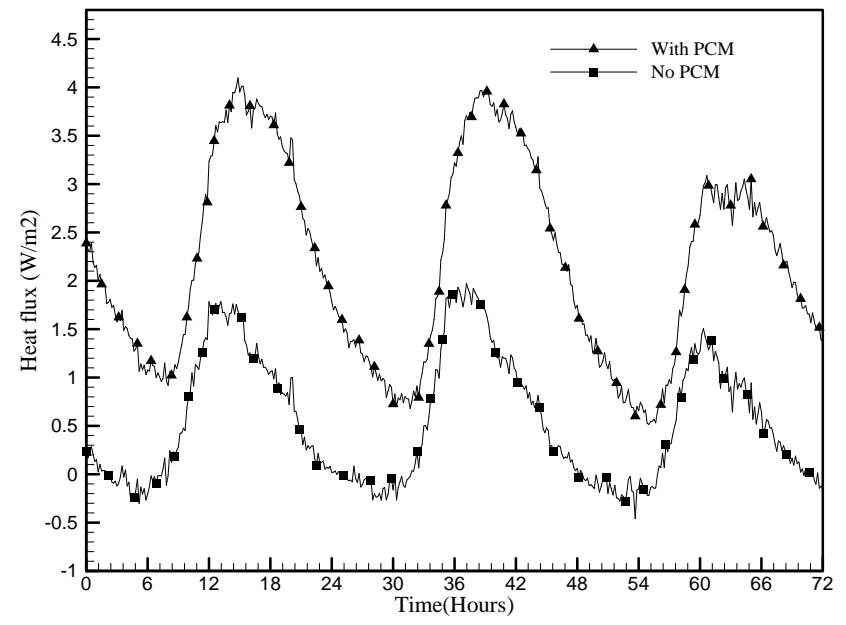

Figure 6: Evolution of conductive thermal gradients via the cubicles south wall

Figure 6 represents the conductive thermal gradients via the south walls. It is found that the heat flux exchanged by conduction through this wall is very important in the PCM cell. Indeed, there are very significant reductions in solar energy gain through the ceiling with PCM. This significantly reduces the ambient temperature of the cell as shown in Figure 5, which causes an increase in heat flow through the vertical walls. The heat flux flow reaches $2.5 \mathrm{~W} / \mathrm{m}^{2}$ in the reference and cell exceeds $4 \mathrm{~W} / \mathrm{m}^{2}$ in the PCM cell. In the case of roof with PCM thermal gradient can be negative at night because the indoor air remains warmer than the outdoor.

\section{CONCLUSION}

Experimental investigation of the thermal performance of composite concrete/PCM cubicles constructed within the Faculty of Science Ain Chock in Casablanca city, Morocco, equipped with a phase change material, in vertical walls and on the roof, was performed. The results showed a significant 
reduction of indoor temperature fluctuations due to absorption and release of solar gains in the composite wall in conjunction with melting of the PCM. The results showed that thermal load of the cubicle containing PCM was reduced compared to the case without PCM with more constant conditions during the heating period. This study showed also that the integration of PCM in the roof lowers the temperature of inner side walls and reduces the amplitude of the oscillations of the temperature of about $2{ }^{\circ} \mathrm{C}$ during the air refreshing period. It was emerged that the cubicle with $\mathrm{PCM} /$ concrete walls is able to provide good performance. The thermal conditions of the indoor environment achieved with the presence of PCM panels were considerably improved compared to cubicle without PCM.

\section{ACKNOWLEDGEMENT}

The present work was financially supported by the Innotherm R\&D project -IRESEN-Morocco.

\section{REFERENCES}

[1] H.G. Barkmann, F.C. Wessling, Use of building structure components for thermal storage, Processing of the Workshop on Solar Energy Storage Subsystems for Heating and Cooling of Building, Charlottesville, VA, USA, 1975.

[2] Kedl RJ, Stovall TK, Activities in support of the waximpregnated wallboard concept. Thermal energy storage researches activity review. New Orleans, Louisiana, USA: US Department of Energy; 1989.

[3] Salyer IO, Sircar AK. Phase change material for heating and cooling of residential buildings and other applications. In: Proceedings of $25^{\text {th }}$ intersociety energy conservation engineering conference; 1990. p. 236-243.

[4] Shapiro MM, Feldman D, Hawes D, Banu D. PCM thermal storage in wallboard. In: Proceedings 12th passive solar conference, Portland; 1987. p. 48-58.

[5] Shapiro M. Development of the enthalpy storage materials, mixture of methyl stearate and methyl palmitate. Subcontract report to Florida Solar Energy Center; 1989.

[6] Feldman D, Khan MA, Banu D. Energy storage composite with an organic phase change material. Solar Energy Mater 1989;18:333-41.

[7] Li. B. Z, Zhang C.L, Deng A. Study on improving indoor thermal environment in light weight building combining PCM wall and nighttime ventilation. Journal of Civil Architectural \& environmental Engineering 31(3) 2009.

[8] J.Paris, Villain, J.-F Houle. Incorporation of PCM in wallboards: a review of recent developments. In: Proceedings of the First World Renewable Energy Congress, September, Reading, UK, pp. 2397-2401, 1990.

[9] M. Faraji, Numerical computation of solar heat storage in phase change material/concrete wall. International Journal of Energy and Environment, vol 5, (3).353360,2014.

[10] Castell A, Martorell I, Medrano M, Pérez G, Cabeza LF. Experimental study of using PCM in brick constructive solutions for passive cooling. Energ Buildings 2010;42:534-540. ASHRAE. (2009). 2009

[11]ASHRAE Handbook - Fundamental(SI), http://www.techstreet.com/ashrae /products/1858361?ashrae_auth_token=.

[12] Rubitherm Technologies $\mathrm{GmbH}$, Internet: www.rubitherm.com, Data sheet, Date: 23.07.2013. 